\title{
Frequency of Verticillium Species in Commercial Spinach Fields and Transmission of V. dahliae from Spinach to Subsequent Lettuce Crops
}

\author{
D. P. G. Short, S. Gurung, S. T. Koike, S. J. Klosterman, and K. V. Subbarao
}

First, second, and fifth authors: Department of Plant Pathology, University of California, Davis, c/o United States Department of Agriculture Research Station, 1636 E. Alisal Street, Salinas, CA 93905; third author: University of California Cooperative Extension, Salinas, CA 93901; and fourth author: United States Department of Agriculture-Agricultural Research Service, Salinas, CA 93905.

Accepted for publication 21 July 2014.

\begin{abstract}
Short, D. P. G., Gurung, S., Koike, S. T., Klosterman, S. J., and Subbarao, K. V. 2015. Frequency of Verticillium species in commercial spinach fields and transmission of $V$. dahliae from spinach to subsequent lettuce crops. Phytopathology 105:80-90.

Verticillium wilt caused by $V$. dahliae is a devastating disease of lettuce in California (CA). The disease is currently restricted to a small geographic area in central coastal CA, even though cropping patterns in other coastal lettuce production regions in the state are similar. Infested spinach seed has been implicated in the introduction of $V$. dahliae into lettuce fields but direct evidence linking this inoculum to wilt epidemics in lettuce is lacking. In this study, 100 commercial spinach fields in four coastal CA counties were surveyed to evaluate the frequency of Verticillium species recovered from spinach seedlings and the area under spinach production in each county was assessed. Regardless of the county,

$V$. isaacii was the most frequently isolated species from spinach followed by $V$. dahliae and, less frequently, V. klebahnii. The frequency of recovery of Verticillium species was unrelated to the occurrence of Verticillium wilt on lettuce in the four counties but was related to the area under spinach production in individual counties. The transmission of $V$. dahliae from infested spinach seeds to lettuce was investigated in microplots. Verticillium wilt developed on lettuce following two or three plantings of Verticillium-infested spinach, in independent experiments. The pathogen recovered from the infected lettuce from microplots was confirmed as $V$. dahliae by polymerase chain reaction assays. In a greenhouse study, transmission of a green fluorescence protein-tagged mutant strain of $V$. dahliae from spinach to lettuce roots was demonstrated, after two cycles of incorporation of infected spinach residue into the soil. This study presents conclusive evidence that $V$. dahliae introduced via spinach seed can cause Verticillium wilt in lettuce.
\end{abstract}

Many plant pathogens have inadvertently been disseminated via infected plant material, including seed, on a global scale. In recent years, this dissemination has occurred at unprecedented rates $(8,34)$. Often their spread may be overlooked until the pathogens become widely distributed and problematic $(14,33)$. Identifying the actual vectors of pathogen dissemination therefore plays a key role in understanding the spread of diseases across geographic borders (25). One of the best documented plant pathogen invasions is the introduction of the oomycete Phytophthora infestans, via infected potato (Solanum tuberosum) tubers (into Europe in the mid-1840s), leading to the Irish potato famine (30). Other examples of emerging infectious diseases transmitted through infested plant material include rice blast (1) and karnal bunt of wheat (7). While some invasions can be eradicated if detected early, the prevention of biological invasions is the most cost-effective strategy of invasive species control (25).

Verticillium dahliae is a soilborne pathogen that causes economically significant wilt diseases of more than 400 plant species worldwide including lettuce (Lactuca sativa) $(6,27,35)$. The disease has also been reported on seed crops of spinach (Spinacia oleracea) (10) but its economic significance in seed production is unknown. The pathogen is endemic in the spinach seed production

Corresponding author: K. V. Subbarao; E-mail address: kvsubbarao@ucdavis.edu

First two authors contributed equally to this work.

http://dx.doi.org/10.1094/PHYTO-02-14-0046-R

This article is in the public domain and not copyrightable. It may be freely reprinted with customary crediting of the source. The American Phytopathological Society, 2015. areas of northern Europe and Washington State in the United States and correspondingly, a high percentage of spinach seed lots produced in these areas can be infested with $V$. dahliae (10). Even though California (CA) produces more than $78 \%$ of the total spinach crop in the United States, and almost half of this crop is produced in Monterey County alone $(2,3)$, no spinach seed is produced in CA because of the inadequate day length needed to induce flowering (=bolting). Seed produced in northern Europe, Chile, New Zealand, or Washington is the sole source of seed for crop production in CA. Because leafy spinach crops are harvested before the onset of bolting and, therefore the onset of Verticillium wilt symptoms, the disease is not an economic threat to spinach production in CA. However, the pathogen introduced by infested spinach seed has the potential to become a major problem on crops susceptible to Verticillium wilt that follow spinach.

In coastal $\mathrm{CA}$, spinach and lettuce are often rotated with each other, and agricultural practices and cropping patterns are similar in both the northern and southern parts of this coastal region. Verticillium wilt has affected several fruit and vegetable crops for decades $(16,38)$ in this area, but lettuce was historically considered immune to this pathogen. This changed, however, when Verticillium wilt in lettuce was first observed in a small number of fields in Watsonville (Santa Cruz County) during 1995 (35), and since then this pathogen has become a serious problem in lettuce in both the Salinas (Monterey County) and Pajaro (Santa Cruz County) Valleys. The disease has so far not been observed in other major lettuce producing valleys of CA, including the Santa Maria (Santa Barbara County) and San Juan (San Benito County) Valleys. The reasons the disease is currently confined to the Pajaro and Salinas Valleys of CA are unknown. 
Verticillium dahliae can be disseminated easily. The pathogen can be introduced into new fields or areas via infested seeds, planting material, and soil $(11,27)$. Previously, it was shown that $92 \%$ of the commercial seed lots assayed from Denmark, New Zealand, The Netherlands, and the United States were infested with Verticillium species to varying degrees, while transmission of $V$. dahliae across spinach generations ranged from 0 to $100 \%$ (9). In infested seed, V. dahliae colonizes the pericarp, seed coat, cotyledons, and radicle, and can form approximately 250 microsclerotia per seed (24). Seedborne $V$. dahliae is transmitted systemically into the tissue of spinach seedlings and subsequently to the flowers and seeds in spinach plants grown for seed (24). In spinach production fields, the crop is harvested prior to symptom development, though the pathogen can become a part of the resident soil microbial community when the crop residue is incorporated into the soil. Fungicide treatments of infested spinach seeds tested to date reduce but do not eliminate viable inoculum of $V$. dahliae from seeds (24).

Population genetic analyses using microsatellite markers revealed that spinach populations of $V$. dahliae from Denmark, The Netherlands, and the United States (Washington) were similar to populations collected from infected lettuce in coastal CA (5). This suggested an association between $V$. dahliae in spinach seed and lettuce. Subsequent work documented significant gene flow within the spinach populations and among populations from infested spinach seed and lettuce (6) and concluded that anthropogenic movement of infested spinach seed had contributed to the epidemics of Verticillium wilt in lettuce in the Salinas and Pajaro valleys (6).

Immigration of novel genotypes or races is a particularly serious concern as it interferes with the ability of breeders to select for durable resistance (26). Previously, more than $90 \%$ of the $V$. dahliae isolates collected from spinach seed were identified as race 2 based on polymerase chain reaction (PCR) assays (31). Although $V$. dahliae populations sampled from lettuce fields in the Salinas and Pajaro valleys between 1995 and 2013 were highly clonal and dominated by race 1 (15), the unrestricted influx of novel $V$. dahliae genotypes or races via infested spinach seed (6) may lead to changes in the population and race structure of $V$. dahliae in these regions. Thus, the successful efforts over the past 15 years in developing $V$. dahliae race 1 resistance in lettuce cultivars (17) may be compromised. Additionally, V. dahliae isolates from spinach seed have been shown to cause severe Verticillium wilt in several crops, including cotton, lettuce, and tomato under greenhouse conditions $(18,23)$. Likewise, 53 arbitrarily selected $V$. dahliae isolates from spinach seeds caused Verticillium wilt in the race 1-resistant lettuce cultivar La Brillante (which contains the Vrl gene that confers resistance against race 1) (31). Despite these greenhouse and laboratory experiments, direct evidence linking $V$. dahliae introduced into a field from spinach seeds and Verticillium wilt in subsequent lettuce crops is lacking. Furthermore, species of Verticillium other than $V$. dahliae have also been isolated from spinach seed $(18,37)$. The frequency of these species introductions into spinach production fields and their eventual impact on other crops are currently unknown.

The current study investigated the potential role of $V$. dahliae inoculum introduced via infested spinach seed on Verticillium wilt in subsequent lettuce crops and assessed the reasons why the disease is currently restricted to the Salinas and Pajaro valleys in CA. Specifically, the objectives of this study were (i) to investigate why Verticillium wilt of lettuce is confined to two valleys in CA by determining the diversity and frequency of isolation of Verticillium in commercial spinach fields and the area under spinach production; and (ii) to determine the ability of $V$. dahliae inoculum from infested spinach seeds to spread to the roots of the subsequent lettuce crop using an alternating spinach-lettuce cropping pattern, and by using spinach seedborne green fluorescence protein (GFP)-tagged $V$. dahliae isolate to track its invasion of soil and lettuce roots.

\section{MATERIALS AND METHODS}

Spinach field survey and isolation of Verticillium species. The incidence and identity of Verticillium species in major commercial spinach fields from Monterey, San Benito, Santa Barbara, and Santa Cruz counties in CA were investigated. There were 69 and 31 fields surveyed during 2011 and 2012, respectively (Fig. 1). Twenty spinach plants were arbitrarily collected from each commercial spinach field when the crops were at market maturity. The plants were washed free of soil and debris, surface-sterilized in $1 \% \mathrm{NaOCl}$ (Clorox, The Clorox Company, Oakland, CA), and rinsed for 20 to $30 \mathrm{~s}$ with sterile distilled water (SDW). After surface disinfestation, the plant samples were left in a laminar flow hood on paper towels for 1 to $2 \mathrm{~h}$ to dry. The roots and petioles were then dissected and plated on sodium polypectate agar (NP-10 agar) (22). Verticillium colonies were putatively identified to species after 9 to 14 days on NP-10 agar based on the colony morphology, conidiophore branching, microsclerotia production, and yellow pigmentation (19). Since $V$. isaacii and V. klebahnii are morphologically cryptic (19), no attempt was

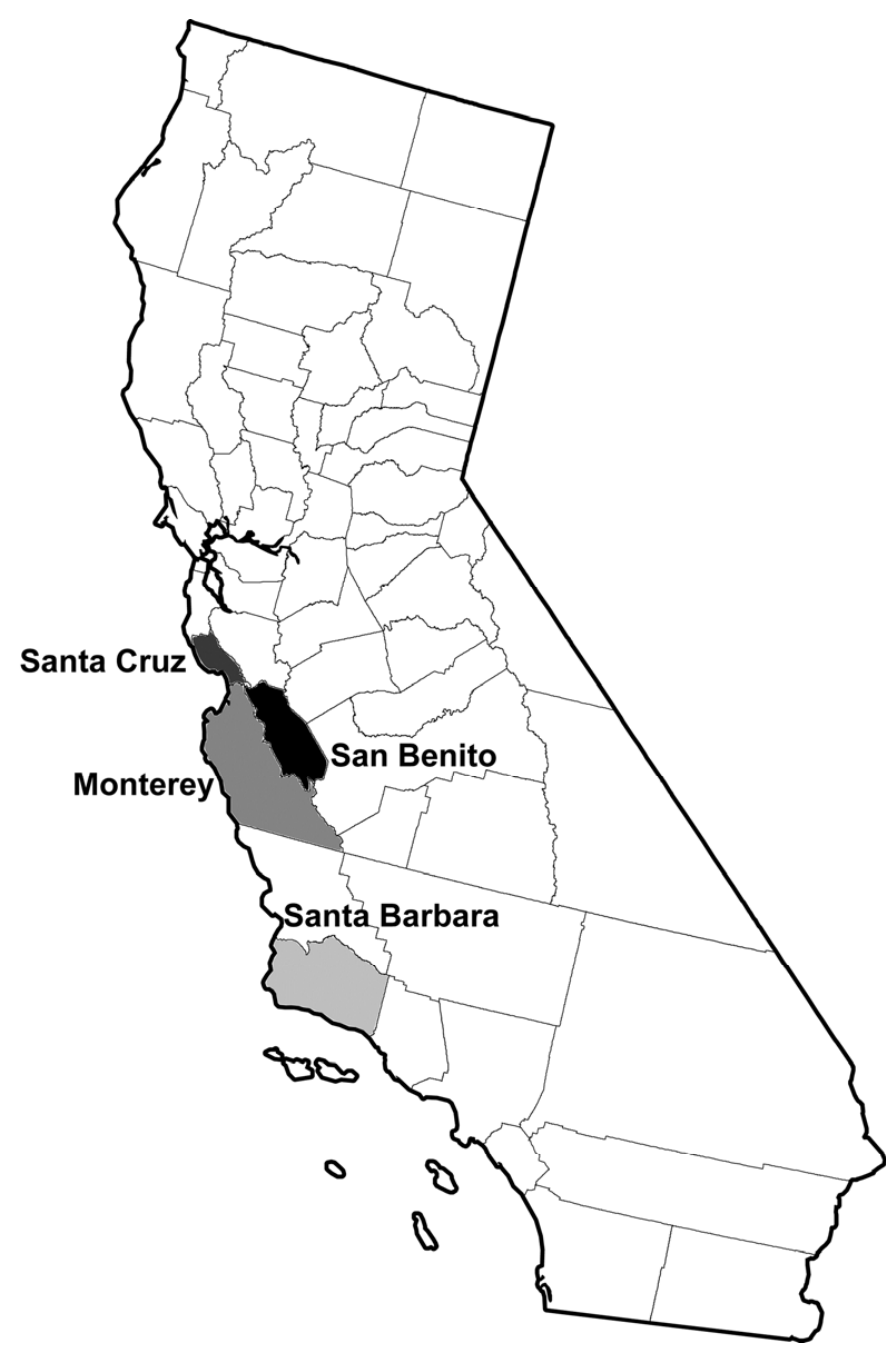

Fig. 1. Map showing the four counties (Monterey, San Benito, Santa Barbara, and Santa Cruz) of California where 69 and 31 major commercial spinach fields were surveyed during 2011 and 2012, respectively, for determining the incidence and species identity of Verticillium species. Whole spinach plants were sampled randomly from each field, and fungal isolations from the roots and petioles using semiselective media were performed to determine the incidence of plants infected. 
made to distinguish the two through microscopy. Cultures were then transferred to potato dextrose agar (PDA) and single-spored. Colonies derived from single spores were transferred to potato dextrose broth (PDB) and grown for 7 to 10 days. The mycelium was harvested, washed with SDW, lyophilized, and ground to a fine powder with a high-speed mixer mill (Model MM301, Retsch Inc., Newtown, PA). Genomic DNA of each isolate was extracted using a FastDNA Kit (MP Biomedicals, LLC, Solon, OH). A NanoDrop (Model ND-1000, Thermo Scientific Inc., Waltham, MA) instrument was used to quantify the DNA in each sample and $1 \mu \mathrm{l}$ of DNA $(10 \mathrm{ng} / \mu \mathrm{l})$ was used for PCR assays.

Verticillium species identification using PCR assays. Three hundred fifty-eight Verticillium isolates from spinach field surveys that were putatively identified to species using morphological and cultural characteristics were characterized to phylogenetic species using PCR assay as previously described (20). PCR assays were performed in 25- $\mu$ l reactions using GoTaq Green Mastermix (Promega, Madison, WI). All of the PCR assays used in this study were carried out in a PTC-100 Peltier Thermal cycler (MJ Research, Inc., Waterman, MA). The following thermal profile was used for PCR: $2 \mathrm{~min}$ of initial denaturation at $94^{\circ} \mathrm{C}$; 35 cycles of $30 \mathrm{~s}$ at $94^{\circ} \mathrm{C}, 30 \mathrm{~s}$ min at $68^{\circ} \mathrm{C}$, and $1 \mathrm{~min}$ at $72^{\circ} \mathrm{C}$; and $10 \mathrm{~min}$ final extension at $72^{\circ} \mathrm{C}$. Six microliters of SyberGold (Invitrogen, Carlsbad, CA) was added to PCR amplicons, which were then separated in $2 \%(\mathrm{wt} / \mathrm{vol})$ agarose gels in $0.5 \times \mathrm{TBE}$ buffer $(0.089 \mathrm{M}$ Tris-borate, $0.089 \mathrm{M}$ boric acid, and $0.002 \mathrm{M}$ EDTA). Gels were each run for $120 \mathrm{~min}$ at $75 \mathrm{~V}$ and visualized with a transilluminator (UVP, Upland, CA). A 100-bp DNA ladder (Invitrogen Corporation, Carlsbad, CA) was used as a size marker in each gel.

Microplot soil preparation. Microplots (each $1.2 \times 1.2 \mathrm{~m}^{2}$ ) established at the U.S. Department of Agriculture Research Station in Salinas, CA, were used for this study. To prevent potential interference from background of Verticillium spp. that may have been present, soil in each microplot was excavated to a depth of $90 \mathrm{~cm}$, and the excavated microplots were refilled with soil obtained from a local nursery (McShane Nursery, Salinas, CA). The soil used in the experiment was an Antioch sandy loam (45.8\% sand, $43.4 \%$ silt, $8.8 \%$ clay, and $1.8 \%$ organic matter) with a $\mathrm{pH}$ of 7.1. Soil from each microplot was collected and assayed for $V$. dahliae by impaction plating onto NP-10 agar using the Anderson sampler technique $(9,22)$. The assay revealed that $V$. dahliae colony forming units, such as microsclerotia, in microplot soils were undetectable.

Spinach seed infestation treatments. A sample of spinach seed obtained from a commercial seed company was surfacedisinfested in $1 \% \mathrm{NaOCl}$ for $1 \mathrm{~min}$, rinsed in SDW, air dried, and plated on NP-10 agar to assess the percentage of seed infested with $V$. dahliae. In each of two separate experiments, 600 seeds were plated and the number of seeds harboring $V$. dahliae was recorded, for a total of 1,200 seeds. Based on these data, the infestation level of the seed lot was determined to be approximately $67 \%$ infested seeds. Seeds from this lot were then mixed with treated seeds of the same cultivar from a different lot (treated with proprietary material to eliminate seedborne Verticillium spp. by the seed company that provided the seed) to produce five infestation levels (=treatments). Five treatments established in the microplots consisted of planting spinach seed with infestation levels of approximately 0\% (all seed treated), 10\%, 15\%, 33\% (these latter three treatments contained a mixture of treated and nontreated seed), and 67\% (all nontreated seed). Four replications of each treatment were planted $(\approx 7$ million per hectare, equivalent to $\approx 1,600$ seeds per plot) into microplots that were arranged in a complete random block design. Four microplots were not sown with any spinach seed and were used as negative controls. The microplots for each treatment were fixed for the duration of the study. Cultural practices were followed in accordance with the standard procedures for spinach production. The microplots were regularly irrigated with drip tape throughout the experiment. A urea-nitrate fertilizer (Wilbur-Ellis County, Salinas, CA) was applied to microplots at the rate of $124 \mathrm{~kg} / \mathrm{ha}$ at 3 -week intervals. To simulate harvesting practices typical of commercial production, twice during each crop, spinach leaves were harvested with hand shears that were cleaned between microplots. Three successive crops of spinach were grown in each microplot during the first year (2011) followed by one lettuce crop. The next year (2012), two successive spinach crops were followed by one crop of lettuce.

Soil and spinach plant sampling. To obtain the baseline inoculum density of $V$. dahliae for each microplot, soil samples were collected from each microplot before planting any crops. To estimate inoculum added to the soil from infested spinach seed, soil was assessed 1 to 2 weeks after the first spinach leaf harvest and 1 to 2 weeks after the incorporation of spinach crop residue. Five soil samples were collected from the top $10 \mathrm{~cm}$ of each microplot using a trowel, which was cleaned with $70 \%$ ethanol in between collecting soil from different microplots. Soil was pooled from each microplot, air dried, pulverized, and plated onto NP-10 agar (22) using an Anderson sampler $(9,22)$ and incubated in the dark at ambient temperature. After 2 weeks, plates were washed and examined under a dissecting microscope for the presence of microsclerotial colonies characteristic of $V$. dahliae (19).

To assess the incidence of plants colonized by $V$. dahliae within spinach seedlings, plants were collected from each microplot at least twice during each spinach crop in the first year (2011), and sampled once during each spinach crop in the second year (2012). During each sampling, 20 spinach seedlings were arbitrarily collected from each microplot, cleaned with SDW, soaked in $1 \%$ $\mathrm{NaOCl}$ for $1 \mathrm{~min}$, rinsed in SDW, and air-dried in a laminar flow hood for $1 \mathrm{~h}$. The roots were dissected into 0.5 to $1 \mathrm{~cm}$ pieces and plated on NP-10 agar, incubated for 2 to 3 weeks in the dark at ambient temperature, and examined under a dissection microscope. To mimic residue incorporation in commercial fields, after each spinach crop, residual plant tissue was incorporated into the microplot soil with a gardening hoe, which was cleaned with water in between treatments.

Lettuce cultivation in microplots. Lettuce cultivar Salinas was planted in each microplot after the completion of three crops of spinach in the first year and two crops of spinach in the second year. The lettuce seed lot was obtained from the laboratory of R. Hayes, USDA-ARS, and screened for the presence of $V$. dahliae prior to planting by plating 50 replicates of 20 seeds per plate on NP-10 agar. The lettuce seed lot was determined to be uninfested. Two raised beds were prepared within each microplot and each was direct seeded with two rows of lettuce seed $25 \mathrm{~cm}$ apart. In each row, lettuce was planted at $20 \mathrm{~cm}$ plant spacing for a total of 24 plants per microplot. Plants were irrigated with drip tape running parallel to the rows and the lettuce was grown according to standard commercial practice. At market maturity, plants were uprooted and the taproots were cut longitudinally up to the crown and the presence or absence of vascular discoloration typical of Verticillium wilt in lettuce was determined. Plants with symptoms typical of Verticillium wilt were collected and Verticillium spp. isolates were obtained in the laboratory as described above for spinach.

Molecular identification of fungi isolated from lettuce. Verticillium isolates from lettuce grown in microplots were transferred from NP-10 agar with a pipette tip, mixed with $80 \mu \mathrm{l}$ of SDW, and spread onto PDA with a cell spreader. Single-spore colonies were obtained, transferred to PDB, and grown for 7 to 10 days. DNA extraction and PCR assays were performed as described above. The presence of $V$. dahliae on lettuce within microplots was confirmed using a $V$. dahliae-specific PCR assay (20).

Transmission of a GFP-tagged strain of $V$. dahliae from spinach to lettuce. Seeds of spinach cultivar Hector, infested with the GFP-expressing spinach strain VdSo925-316 (24), were 
planted in 10 cups (10 seeds/0.94 liter Styrofoam cup) in a pasteurized 3:1 sand/all-purpose potting soil mix (Sun Land Products, Inc., Watsonville, CA). The experiments were conducted in a greenhouse located at the USDA-ARS Station, Salinas, CA under natural light conditions between 30 July and 14 December 2013. For temperature control, fan-forced radiant heat was on below $18^{\circ} \mathrm{C}$ and an automatic exhaust fan with evaporative cooling was on above $24^{\circ} \mathrm{C}$. Seventy-five percent of the spinach seeds were infested with $V$. dahliae (234/312) as determined by NP-10 agar plate analyses described previously (12). Approximately 6 weeks after planting, whole spinach plants were uprooted, chopped into $1 \mathrm{~cm}$ pieces, and allowed to dry on the surface of the sand soil mixture for 5 days. After the drying period, more of the SoVd316-GFP-infested spinach seeds were planted into the same 10 cups and soil mix (10 seeds per cup) and grown for approximately 6 weeks. The plants were uprooted, chopped into pieces as before, and allowed to dry on the surface of the sand/potting soil mix for approximately 1 week. Following two sets of spinach, lettuce cultivar Salinas was planted, also at 10 seeds per cup, in five of the same cups containing the dried spinach debris. Seeds of Hector not infested with SoVd316-GFP were planted into the other five cups at a rate of 10 seeds per cup for the final spinach planting. After 5 weeks, both lettuce and spinach plants were uprooted, the roots were rinsed vigorously with distilled water, and examined for the presence of the GFPexpressing $V$. dahliae strain.

Whole root mounts were examined with an epifluorescence Olympus BX60 compound microscope or a Nikon compound microscope with filter blocks for GFP (450-490 nm excitation, $590 \mathrm{~nm}$ longpass emission), coupled to a Leica confocal laser scanning microscope (CLSM; Leica Microsystems Inc., Buffalo Grove, IL). Confocal images were captured as outlined by Maruthachalam et al. (24). Out of five lettuce root systems from five plants examined, a portion of the root system of a single plant was determined as positive for GFP expression by epifluorescence microscopy. Similarly, of the roots of five spinach plants examined, one was positive for GFP expression. The positive samples were examined further by CLSM analyses $(24,36)$.

Spinach and lettuce production in coastal CA. The areas under spinach (1993 to 2012) and lettuce (1994 to 2012) production in Santa Barbara, San Benito, Santa Cruz, and Monterey counties were compared and plotted against the year of production. Data were obtained from the respective Agricultural Commissioners Offices: Santa Barbara (http://www.countyofsb.org/ agcomm/agcomm.aspx?id=11562), San Benito http://www.cosb.us/ county-departments/agriculture/crop-report), Santa Cruz (http:// ww.scparks.com/crop02.html), and Monterey (http://ag.co. monterey.ca.us/resources/category/crop-reports).

\section{RESULTS}

Distribution of Verticillium species in Monterey, Santa Barbara, San Benito, and Santa Cruz counties of CA. Commercial spinach fields were surveyed in four counties in the current study (Fig. 1). Of the 1,380 total spinach plants analyzed in 2011, 585 plants were infected with a Verticillium species; of the 620 plants analyzed in 2012, Verticillium was recovered from 300 plants. Based on an initial assessment of colony morphology and pigment production, $496 \mathrm{~V}$. isaacii/V. klebahnii and 89 putative $V$. dahliae isolates were collected in 2011, while 218 V. isaacii/V. klebahnii and $82 \mathrm{~V}$. dahliae isolates were collected in 2012. The recovery of $V$. dahliae and $V$. isaacii/V. klebahnii from spinach roots and petioles were similar in four counties during 2011 and 2012, except in Monterey County during 2012, where the recovery of $V$. isaacii/V. klebahnii from spinach roots were almost threefold higher than those from petioles (Fig. 2).

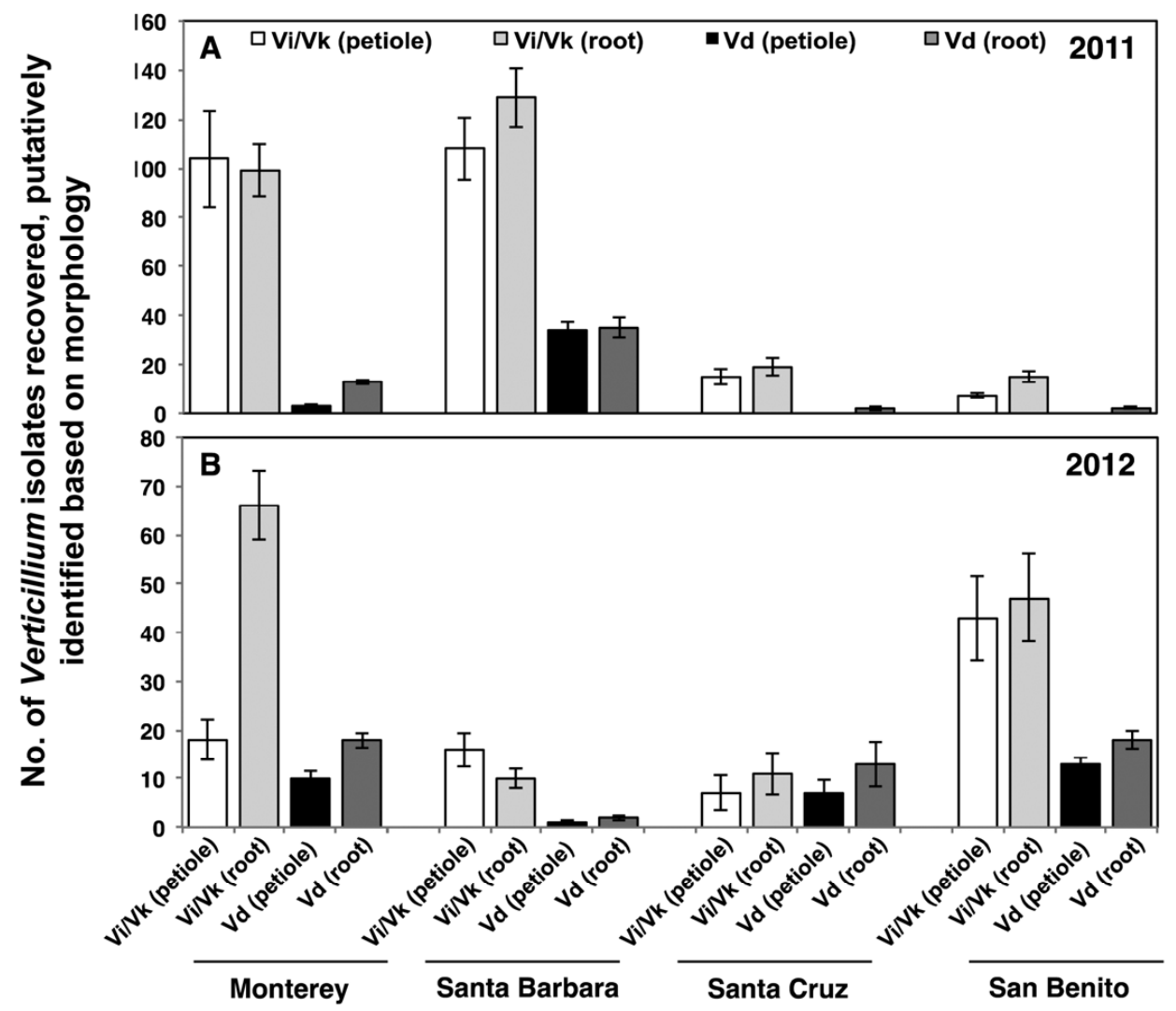

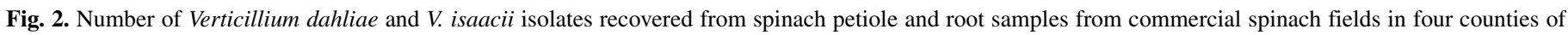

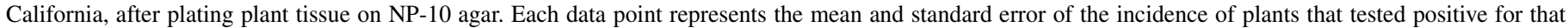

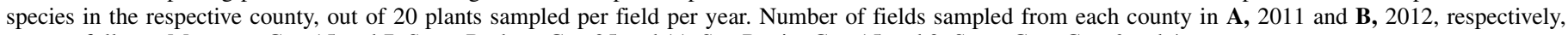
were as follows: Monterey Co., 15 and 7; Santa Barbara Co., 25 and 11; San Benito Co., 15 and 9; Santa Cruz Co., 6 and 4. 
V. isaacii/V. klebahnii were the predominant Verticillium species isolated per field in all counties, with the exception of Santa Cruz County in 2012 (Fig. 3). In 2011, the highest number of V. isaaciil V. klebahnii isolates were recovered from Monterey County, followed by Santa Barbara County. In 2012, the highest number of $V$. isaacii/V. klebahnii isolates were recovered in Monterey County, followed by San Benito County. V. dahliae was recovered with the highest frequency from Santa Barbara County followed by Monterey County during 2011, and Santa Cruz County followed by Monterey County during 2012 (Fig. 3).

Verticillium species identification using PCR assays. Three hundred fifty-eight Verticillium isolates were arbitrarily selected for molecular identification to species using a Verticillium species-specific PCR assay (20). This total included 160 and 198 isolates from 2011 and 2012, respectively, to obtain a representative sample of isolates from both years. Using PCR assays, three Verticillium species (V. dahliae, V. isaacii, and V. klebahnii) were identified from spinach plants (Table 1). Verticillium isaacii was the most frequently isolated, followed by $V$. dahliae, and then V. klebahnii, in each of the four counties (Table 1). With the exception of San Benito County, where V. dahliae was the most predominant species in the 2011 sample, PCR assays confirmed that $V$. isaacii was the predominant species, followed by $V$. dahliae in all four counties (Fig. 2, Table 1). Notably, 10 isolates which were putatively identified as $V$. isaacii based on morphological traits were identified as $V$. dahliae based on PCR assays (Fig. 2, Table 1), indicating that estimates of $V$. dahliae in spinach production fields presented here should be considered conservative and highlighting the importance of molecular identification of Verticillium species (21). In addition, Verticillium isolates from four 2012 samples obtained from Monterey County and two samples from San Benito County were identified as V. klebahnii, based on PCR assays (Table 1).

Isolation of $\boldsymbol{V}$. dahliae from microplot soil. Soil collected before the first spinach crop from all microplots was free of $V$. dahliae (Fig. 4). Microsclerotial colonies of $V$. dahliae from

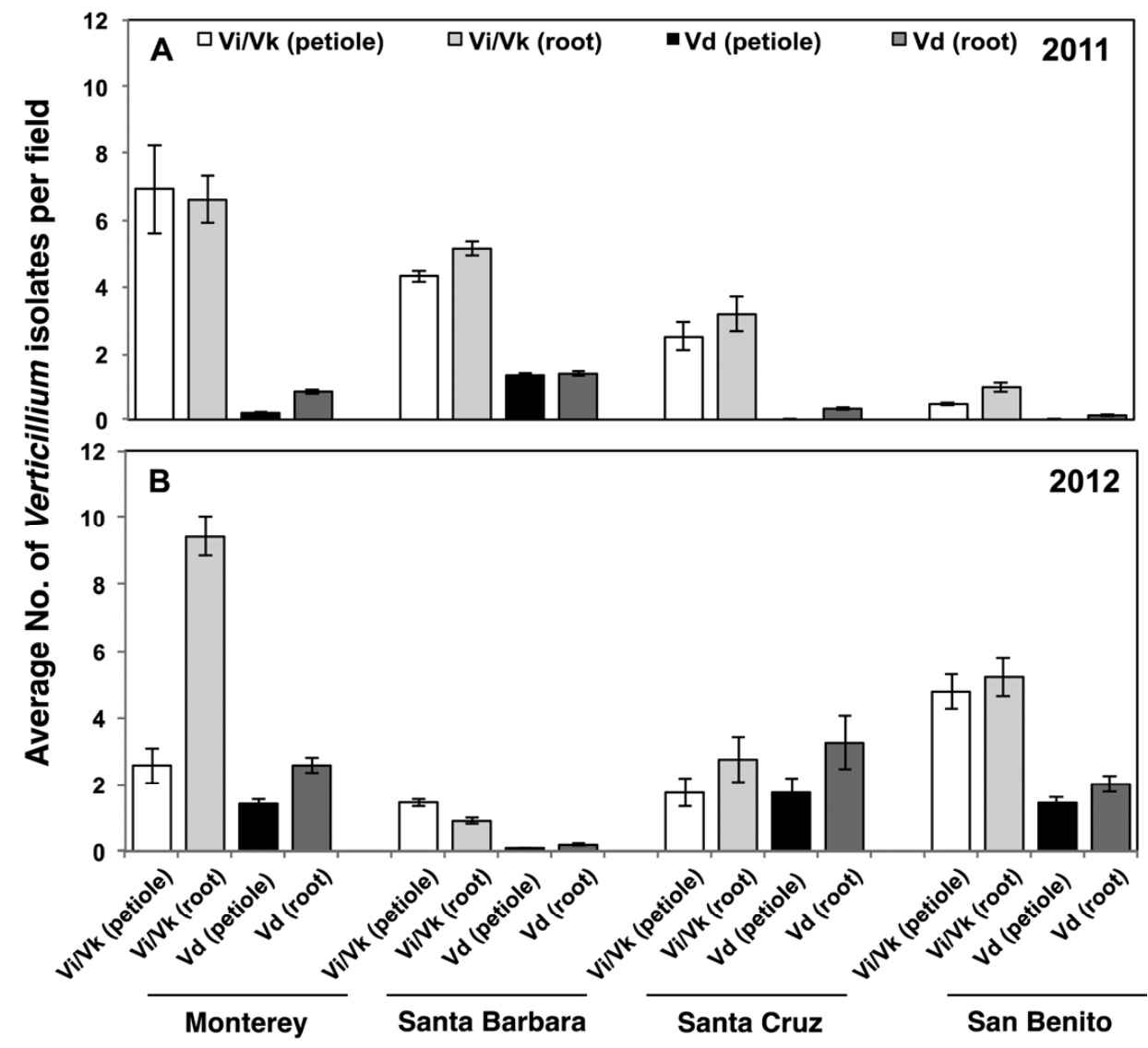

Fig. 3. Verticillium species incidence per field in four counties of California during A, 2011 and $\mathbf{B}, 2012$. Verticillium isolates were recovered from spinach petiole and root samples from commercial spinach fields in four counties of California, after plating plant tissue on NP-10 agar. Each data point represents the mean and standard error of the incidence of plants that tested positive for that species, per field, in the respective county.

TABLE 1. Species identity and number of Verticillium isolates collected from spinach seedlings in commercial spinach crops grown in different counties of California, as determined with Verticillium species-specific polymerase chain reaction (PCR) assays (19)

\begin{tabular}{|c|c|c|c|c|c|c|c|c|}
\hline \multirow[b]{2}{*}{ Location } & \multicolumn{2}{|c|}{ Sample size ${ }^{a}$} & \multicolumn{2}{|c|}{ V. isaacii } & \multicolumn{2}{|c|}{ V. dahliae } & \multicolumn{2}{|c|}{ V. klebahnii } \\
\hline & 2011 & 2012 & 2011 & 2012 & 2011 & 2012 & 2011 & 2012 \\
\hline Monterey & 52 & 62 & 50 & $46^{\mathrm{b}}$ & 2 & 4 & 0 & 4 \\
\hline Santa Barbara & 80 & 4 & 70 & 4 & 10 & 0 & 0 & 0 \\
\hline Santa Cruz & 16 & 30 & 14 & 17 & 2 & 13 & 0 & 0 \\
\hline Total & 160 & 198 & 135 & 152 & 26 & 32 & 0 & 6 \\
\hline
\end{tabular}

${ }^{a}$ A total of 160 and 198 isolates from 2011 and 2012 that were putatively identified to Verticillium species based on morphological and cultural characteristics were arbitrarily selected for molecular identification using a Verticillium species-specific PCR assay (20).

${ }^{\mathrm{b}}$ Eight isolates from Monterey could not be amplified using Verticillium species-specific primers (20). 
soil plated on NP-10 agar were first observed in soil samples collected approximately a month after sowing spinach seeds (time point designated Y1.S1.SMP1 in Fig. 4) in microplots that had levels of seed infestation corresponding to approximately 67, 33, or $15 \%$ infestation treatments (treatments 1,2, and 3). At this time point, the amount of $V$. dahliae inoculum recovered was the highest in microplots sown with $\approx 67 \%$ infested spinach seed, followed by $\approx 33$ and $\approx 15 \%$ (Fig. 4).

Isolation of $\boldsymbol{V}$. dahliae from spinach. Fungal colonies and microsclerotia characteristic of $V$. dahliae were recovered from spinach roots and petioles collected during the first spinach crop after plating on NP-10 agar. Verticillium dahliae was recovered from spinach grown in microplots with the seed infestation treatments of approximately $0,10,15,33$, and $67 \%$ (Fig. 5). Verticillium dahliae recovery from spinach in samples drawn from the $\approx 67 \%$ infestation treatment in the second sample of the third season of year one (Y1.S3.SMP2), and both of the seasons during the second year of the experiment (Y2.S1.SMP1 and Y2.S2.SMP1) was significantly higher than all other treatments (Fig. 5).

Isolation of $\boldsymbol{V}$. dahliae from lettuce in microplots. Verticillium wilt symptoms were visible in a few plants during the first lettuce crop that followed three spinach crops. Plated tissue from symptomatic plants yielded fungal colonies with cultural and morphological traits characteristic of $V$. dahliae, i.e., zonate growth, microsclerotia, and verticillate conidiophores (19). The Verticillium species-specific PCR assay on these isolates confirmed that symptoms of four lettuce plants grown the first year and three lettuce plants grown the second year were indeed caused by $V$. dahliae (gels not shown). Following the first lettuce planting, the incidence of vascular discoloration in lettuce taproots in treatments with approximately 10, 15, 33, and $67 \%$ infested spinach seed was 4.44, 5.26, 9.02, and 9.29, respectively. Similarly, in the second lettuce crop, the incidence of vascular discoloration in lettuce taproots in treatments with approximately $10,15,33$, and $67 \%$ infested spinach seed was 21.43, 26.11, 35.83 , and 31.82 , respectively.

Transmission of a GFP-tagged strain of $\boldsymbol{V}$. dahliae from spinach to lettuce. The GFP-tagged spinach strain VdSo925-316 colonized the lettuce root surface 5 weeks after planting lettuce in soil following two prior plantings of the infested spinach seeds and incorporation of the residue (Fig. 6A). In addition to the result in Figure 6A, another portion of the same lettuce root system was clearly positive for the GFP-expressing fungus (data not shown).

The spinach-to-spinach transmission of strain VdSo925-316 was carried out similarly, and the strain also colonized the spinach root surface (Fig. 6C). The GFP-tagged spinach strain penetrated the root surface as observed by CLSM (arrow in Fig. 6C).

Spinach and lettuce production in coastal CA. Monterey County planted the largest area of spinach and lettuce during 1993 to 2012, and was at least 10- to 12-fold higher than other coastal counties (Fig. 7). Production of spinach in Monterey County increased significantly over the past two decades. From 1994 to 1999, the year when Verticillium wilt of lettuce was first reported in Monterey County, spinach production more than doubled. The spinach and lettuce production areas in the other three counties (Santa Barbara, San Benito, and Santa Cruz) were relatively constant throughout years 1993 to 2012 (Fig. 7).

\section{DISCUSSION}

This work provides an assessment of Verticillium species that occur in spinach seedlings in commercial production fields in CA.

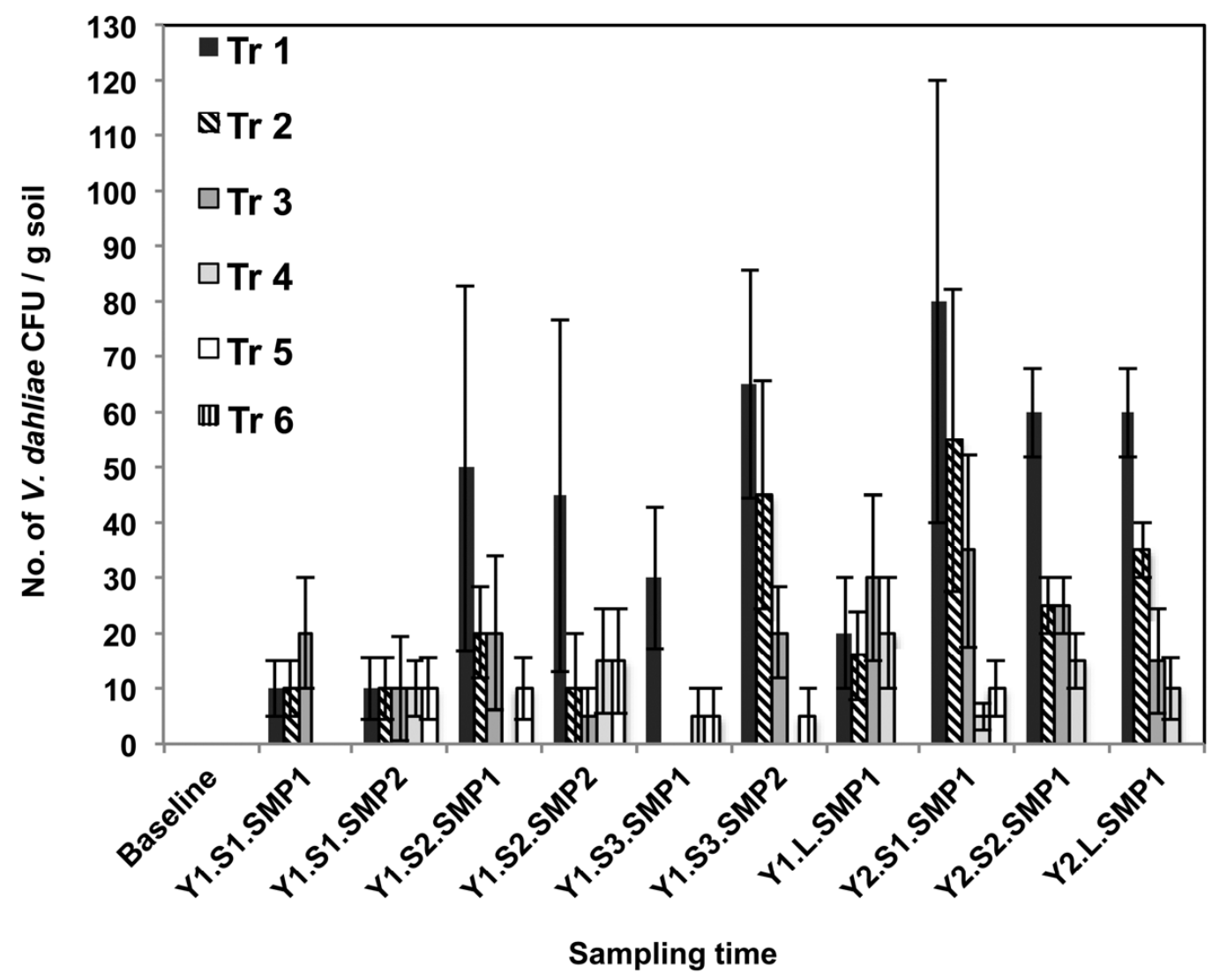

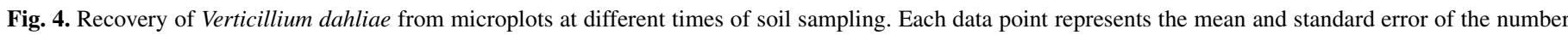

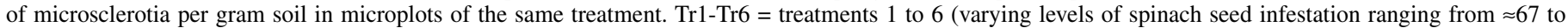

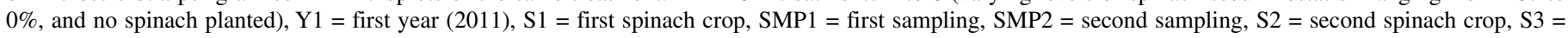
third crop, $\mathrm{L}=$ lettuce crop, $\mathrm{Y} 2$ = second year (2012). Vertical bars represent standard errors. 
Verticillium dahliae, along with V. isaacii and V. klebahnii (19), were recovered from spinach sampled in production fields from four coastal CA counties with significant spinach production. The relative frequency of recovery of individual Verticillium species was unrelated to the occurrence or incidence of Verticillium wilt on lettuce in the four counties. However, in the case of Monterey County, the area of spinach production was highly correlated with the incidence of Verticillium wilt on lettuce (4). The relative importance of the three Verticillium species in the disease complex on lettuce and other coastal CA crops is currently being assessed. These data also clearly establish the missing epidemiological link between $V$. dahliae introduced into the soil by infested spinach seed and the occurrence of Verticillium wilt on lettuce. Based on field and greenhouse studies, a direct connection between $V$. dahliae in infested spinach seed and Verticillium wilt on subsequent lettuce crops was documented.

Based on assessments of cultural characteristics, V. dahliae and isolates consistent with the morphological descriptions of $V$. isaacii and V. klebahnii were recovered from all spinach production counties sampled during 2011 and 2012. With the molecular characterizations of a subset of the isolates collected, $V$. isaacii was recovered in greater frequencies from spinach fields than $V$. dahliae and $V$. klebahnii. The recovery of V. isaacii from petioles of young spinach plants in this study corroborates previous work that shows that at least one species consistent with the morphological descriptions of $V$. isaacii and V. klebahnii (collectively referred to as the outdated morphospecies ' $V$. tricorpus') occur inside spinach seeds $(18,37)$. We hypothesize that it is virtually impossible to recover Verticillium species from petioles at the seedling stage of spinach growth if the pathogen did not originate from within the spinach seed, especially since the fungus is known to colonize seedlings from infected seeds (24). Therefore, based on the average number of $V$. isaacii isolates recovered from each commercial field, it appears that spinach crops introduce $V$. isaacii into commercial fields at comparable frequency, regardless of where the crop is grown.

Dissemination of Verticillium species, especially V. dahliae, via contaminated spinach seed represents a potential threat to agriculture in CA. Verticillium dahliae is known to be associated with Verticillium wilt in many of the agronomically important crops grown in CA $(4,6,35)$. Spinach and lettuce production acreages in Monterey County are 10- to 12-fold higher than in Santa Barbara, San Benito, and Santa Cruz counties, and likely explains why soil inoculum densities of $V$. dahliae may not have increased to the threshold level required for Verticillium wilt development in lettuce crops in Santa Barbara and San Benito counties. While lettuce seeds can also harbor $V$. dahliae, Atallah et al. (6) provided genetic evidence that suggested that $V$. dahliaeinfested spinach seeds are a more likely source of $V$. dahliae inoculum in CA lettuce production than lettuce seeds themselves. Future experimental work following the procedures outlined in the current study should be conducted to elucidate the potential contributions of lettuce seedborne $V$. dahliae in wilt epidemics. Verticillium wilt on lettuce has not been observed in Santa Barbara and San Benito counties. The disease is confined to the Pajaro and Salinas valleys of coastal CA, a region that also includes the other two counties (Monterey and Santa Cruz) compared in this study. Since $V$. isaacii was also commonly recovered from Santa Barbara County, where Verticillium wilt on lettuce has not been reported, we are unable to make any association between $V$. isaacii and Verticillium wilt in lettuce. Interestingly, cauliflower (Brassica oleracea var. botrytis) fields infested with both $V$. longisporum and $V$. isaacii showed fewer Verticillium wilt disease symptoms relative to cauliflower fields with $V$. longisporum alone (13), suggesting that specific $V$. isaacii isolates may suppress disease caused by V. longisporum and other Verticillium species in certain cases (13). Preliminary co-inoculation studies have also demonstrated that colonization of lettuce by certain

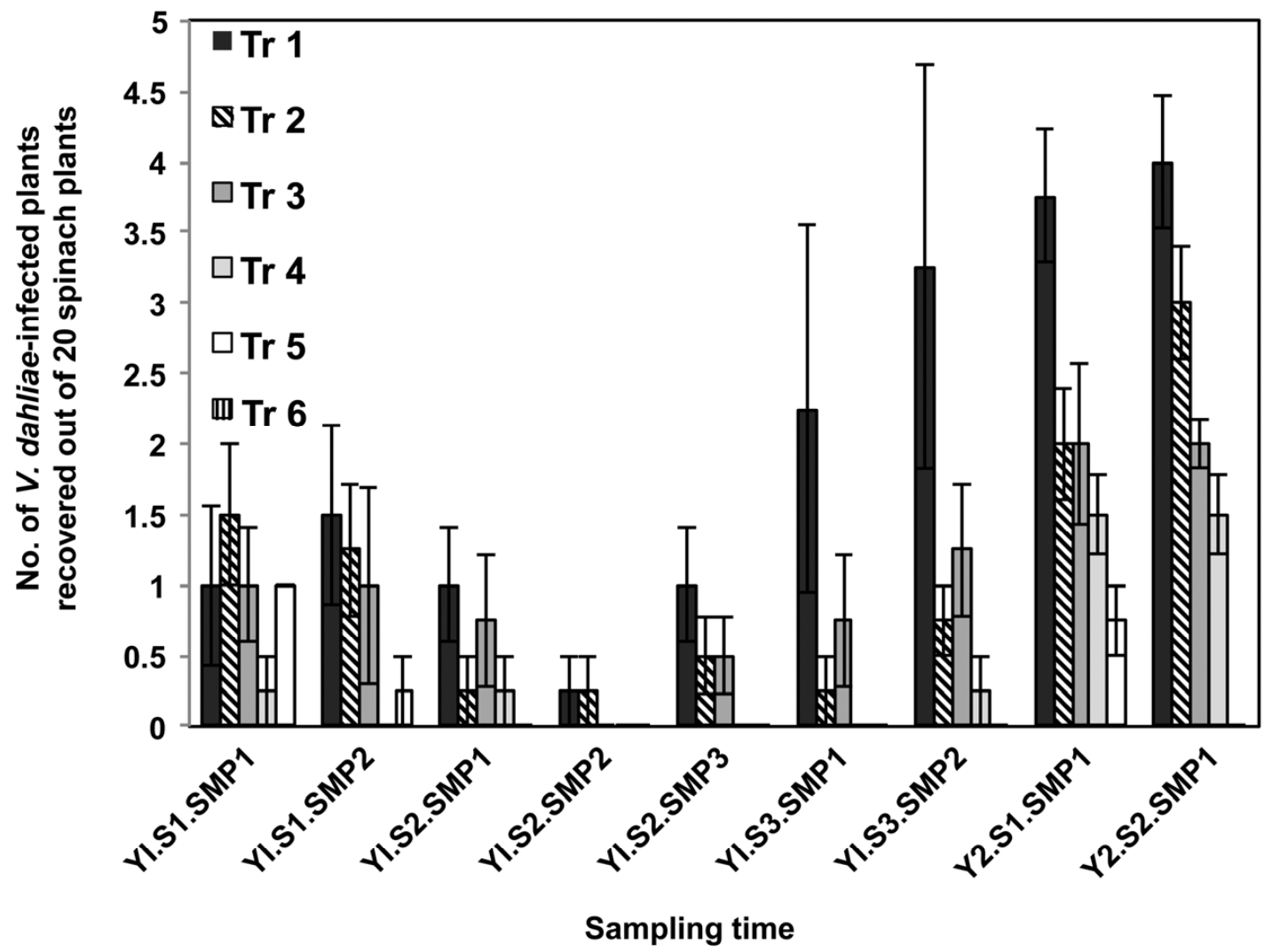

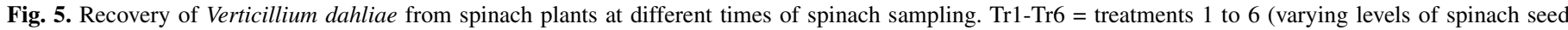

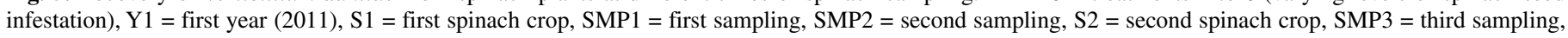
S3 $=$ third spinach crop, Y2 = second year (2012). Vertical bars represent standard errors. 
strains of $V$. isaacii may reduce wilt caused by $V$. dahliae (29). Although $V$. isaacii was recovered frequently along with $V$. dahliae in the same commercial spinach fields, further studies are necessary to elucidate the role of this species, if any, in the etiology of Verticillium wilt in lettuce and other crops grown in CA.

The occurrence of $V$. isaacii and V. klebahnii in spinach fields suggests that these species may be present in major spinach seedsupplying regions, such as northern European countries and WA, and that these Verticillium species might also be associated with other crops grown in those regions. This hypothesis is supported by recent reports of $V$. isaacii associated with Verticillium wilt in a lettuce crop on a research farm in WA (28). Although Powell et al. (28) described several pathogens (Vt.Ls.2010, Vt.Ls.2011-1, and Vt.Ls.2011-2) as "V. tricorpus," sequences of the internal transcribed spacer (ITS) regions of rDNA reveal these isolates to be conspecific with $V$. isaacii (19). Therefore, it is reasonable to suspect that some isolates of $V$. isaacii could cause disease on multiple crops, including lettuce, following rotation with spinach. Given their distribution and potential seedborne nature, future analyses of the pathogenicity of $V$. isaacii and V. klebahnii are essential for understanding the relative importance of these two species as pathogens.

Verticillium dahliae in infested spinach seeds or infected plant tissues can serve as primary sources of inoculum to cause Verticillium wilt in subsequent crops, as demonstrated for lettuce in this study. Verticillium dahliae can produce more than 200 microsclerotia per infested spinach seed (24), and these microsclerotia can remain viable for more than 14 years in the soil in the absence of a host (27). Previous analyses also revealed that it is common to find commercial spinach seed lots with up to $85 \%$ infested seed $(10,12)$. Thus, infested spinach seeds planted at a rate of 7.5 to 10 million seed per hectare can introduce considerable amounts of Verticillium inoculum into the field (24). Since the leaves of spinach production crops are harvested before Verticillium wilt symptoms become evident, economic losses caused by $V$. dahliae on spinach are nonexistent. After harvest, spinach plant residue is incorporated into the soil, along with any $V$. dahliae inoculum that may be present in the plant tissue. This inoculum, which can remain viable for several years, may be amplified through infections of successive lettuce crops to eventually reach the threshold levels to threaten lettuce and other crops. In contrast, a maximum

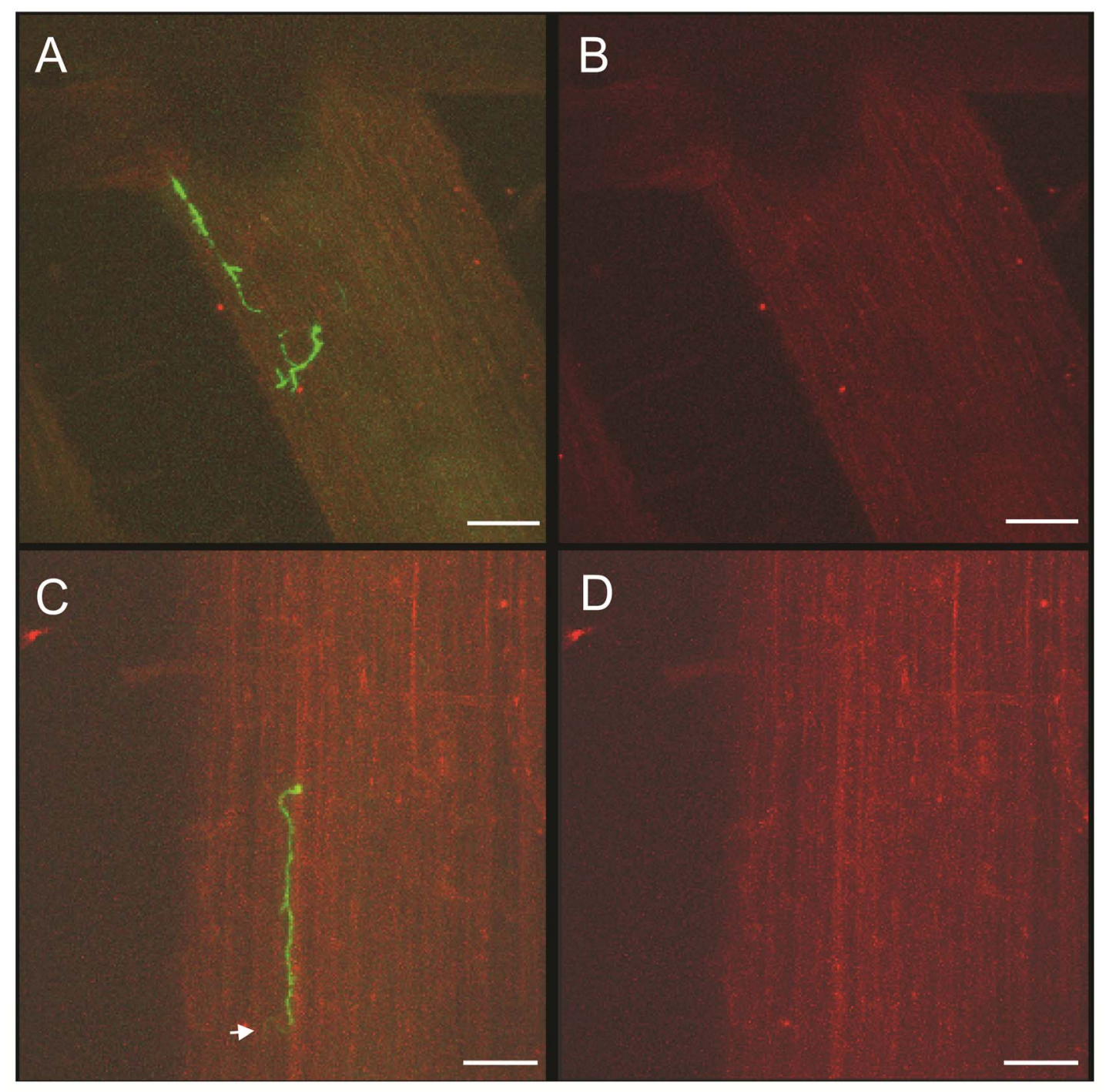

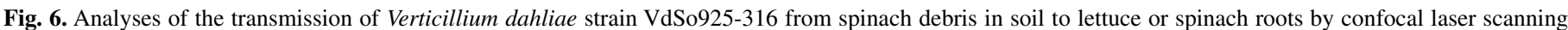

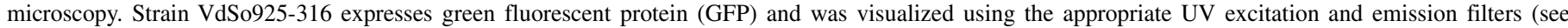

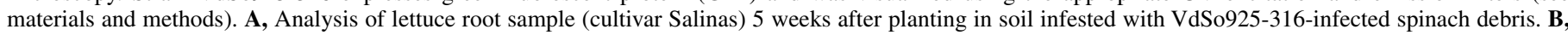

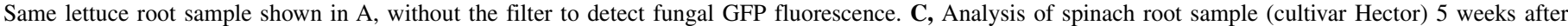

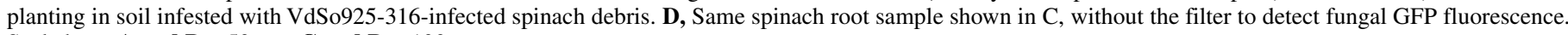
Scale bars: $\mathbf{A}$ and $\mathbf{B}=50 \mu \mathrm{m} ; \mathbf{C}$ and $\mathbf{D}=100 \mu \mathrm{m}$. 
$V$. dahliae infestation rate of $5 \%$ has been detected in lettuce seed (4). However, the proportion of infested seed actually contributing inoculum to lettuce production fields is diminished by processes involved in lettuce production. Lettuce is direct-seeded at a density three to five times higher than the plants retained for crop production post-thinning. Thus, nearly 75 to $83 \%$ of the seedlings regardless of whether they came from healthy or infested lettuce seed are removed during thinning. Depending on the production system, the number of lettuce plants retained per hectare vary from 55,357 to 116,250 (32). The probability that seedlings from infested lettuce seed are successfully retained post-thinning that result in mature, diseased lettuce plants is therefore $\leq 1.25 \%$. Apart from the significant differences between the seeding rates in lettuce $(\approx 166,071$ to 581,250 per hectare) and spinach $(\approx 8$ to 9 million per hectare), spinach seedlings are not thinned, and thus the probability of introducing Verticillium species into the soil is proportional to the level of Verticillium infestation in the planted seed.

Prior to this study, direct evidence linking $V$. dahliae introduced into soil from infested spinach seed with wilt incidence in lettuce was unavailable. This was despite the analyses that had established the genetic similarity of populations of $V$. dahliae from spinach and lettuce (6). By planting alternating crops of spinach and lettuce in microplots in which the soil was devoid of $V$. dahliae microsclerotia or other forms of resting structures, we demonstrated a detectable increase in the $V$. dahliae inoculum in soil after infested spinach seeds were used in crop production. The recovery of $V$. dahliae inoculum from soils in microplots is clear evidence that $V$. dahliae-infested spinach seed introduced microsclerotia into the soil. In addition, the percentage of infested spinach seed planted was correlated with the quantities of microsclerotia in the soil. By the end of the second year of the experiment, the amount of $V$. dahliae inoculum recovered was significantly higher in the microplot soils planted with $\approx 67 \%$ infested spinach seed relative to other treatments where a lower percentage of infested seeds were planted. Similarly, at the end of the first year and during the second year of spinach plant sampling, the amount of $V$. dahliae recovered from spinach seedlings also increased relative to the increasing percentage of infested seed planted in the microplots. This demonstrated that the soil inoculum accumulated relative to the inoculum in seed. Verticillium wilt was observed on the very first lettuce crop following three spinach crops and the incidence levels correlated with the percentage of infested spinach seed planted in the corresponding

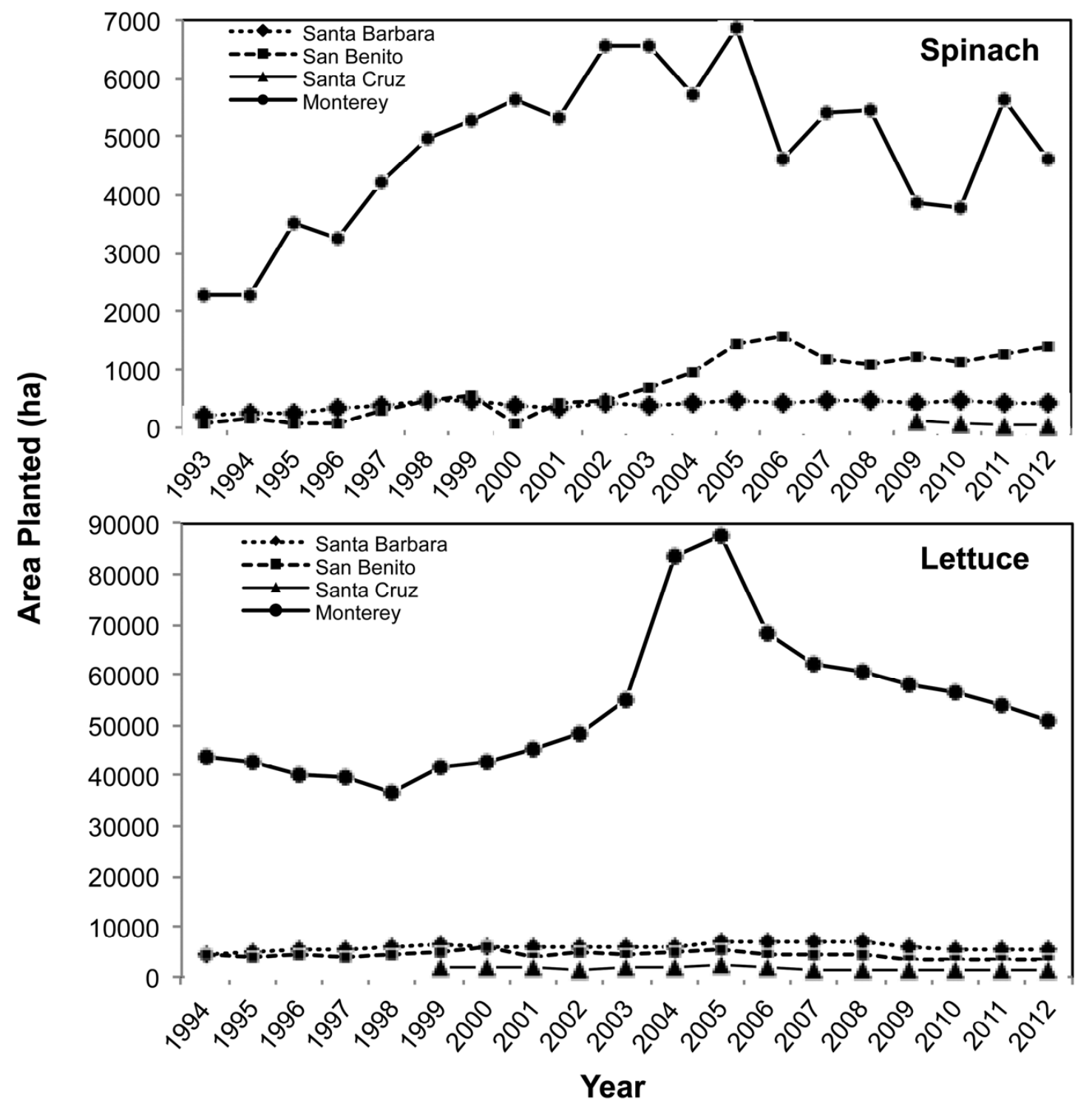

Fig. 7. Area planted with spinach and lettuce in Santa Barbara, San Benito, Santa Cruz, and Monterey counties in different years (Santa Barbara, San Benito, Santa Cruz, and Monterey counties Agricultural Commissioners Offices). 
microplots. It is important to note that economically relevant build-up of microsclerotia in field soil, which could cause higher incidence than what was observed in the microplot experiment, would likely take additional cropping cycles of lettuce, as predicted by recent epidemiological modeling of Verticillium wilt of lettuce (39). The lettuce seed planted in the microplots were not infested with $V$. dahliae; therefore, the sole source of $V$. dahliae for infection of lettuce was the contaminated spinach seed planted in the microplots along with any increases that occurred on spinach crop residue following incorporation into the soil.

The greenhouse studies with the GFP-tagged spinach strain of $V$. dahliae further confirmed the role of $V$. dahliae in infested spinach seed in colonizing subsequent lettuce crops. Previous studies (24) revealed that a GFP-tagged spinach strain of $V$. dahliae colonized the seed of spinach, including deeper seed tissues such as the plumule, hypocotyl, and radical, and that the fungus was transmitted to developing seedlings (24). Seed-to-seed transmission of $V$. dahliae in spinach was also demonstrated by du Toit et al. (10). The studies described herein following the GFP-tagged spinach strain of $V$. dahliae provide definitive evidence that $V$. dahliae naturally occurring in infested spinach seed can and does in fact colonize the root surfaces of subsequent lettuce plants that are planted in the same soil. The lettuce root system colonized by the GFP-expressing strain was observed following two cycles of planting spinach seed with the GFP expressing strain and incorporating spinach residue in soil. Based on the body of evidence, the planting of $V$. dahliae-infested seed is an epidemiologically relevant contributor to the recent, widespread distribution of Verticillium species in the commercial spinach fields surveyed (6). At present, the actual role and impact of $V$. isaacii and V. klebahnii on crops grown in CA is unknown. Thus, it is imperative that pathogenicity tests are conducted for these Verticillium species in the near future. These findings have implications in other crop systems where seedborne pathogens pose problems.

\section{ACKNOWLEDGMENTS}

Funding for this study was provided by USDA-NIFA-SCRI grant no. 2010-51181-21069 and the California Leafy Greens Research Board. We thank S. Benzen, A. Anchieta, P. Ayala, K. Kammeijer, L. Ochoa, D. Renteria, C. Marchebout, and R. Marchebout for their excellent technical assistance.

\section{LITERATURE CITED}

1. Anderson, P. K., Cunningham, A. A., Patel, N. G., Morales, F. J., Epstein, P. R., and Daszak, P. 2004. Emerging infectious diseases of plants: Pathogen pollution, climate change and agrotechnology drivers. Trends Ecol. Evol. 19:535-544.

2. Anonymous. 2011. United States Department of Agriculture-National Agricultural Statistics Service. http://www.nass.usda.gov/Publications/ Ag_Statistics/2011/index.asp

3. Anonymous. 2012. Agricultural Commissioner's Office Monterey Country Crop Report 2011.

4. Atallah, Z. K., Hayes, R. J., and Subbarao, K. V. 2011. Fifteen years of Verticillium wilt of lettuce in America's salad bowl: A tale of immigration, subjugation, and abatement. Plant Dis. 95:784-792.

5. Atallah, Z. K., Maruthachalam, K., du Toit, L., Koike, S. T., Davis, R. M., Klosterman, S. J., Hayes, R. J., and Subbarao, K. V. 2010. Population analyses of the vascular plant pathogen Verticillium dahliae detect recombination and transcontinental gene flow. Fungal Genet. Biol. 47:416-422.

6. Atallah, Z. K., Maruthachalam, K., and Subbarao, K. V. 2012. Sources of Verticillium dahliae affecting lettuce. Phytopathology 102:1071-1078.

7. Bonde, M. R., Peterson, G. L., Schaad, N. W., and Smilanick, J. L. 1997. Karnal bunt of wheat. Plant Dis. 81:1370-1377.

8. Brown, J. K. M., and Hovmoller, M. S. 2002. Aerial dispersal of pathogens on the global and continental scales and its impact on plant disease. Science 297:537-541.

9. Butterfield, E., and DeVay, J. 1977. Reassessment of soil assays for Verticillium dahliae. Phytopathology 67:1073-1078.
10. du Toit, L. J., Derie, M. L., and Hernandez-Perez, P. 2005. Verticillium wilt in spinach seed production. Plant Dis. 89:4-11.

11. Dung, J. K., Hamm, P. B., Eggers, J. E., and Johnson, D. A. 2013. Incidence and impact of Verticillium dahliae in soil associated with certified potato seed lots. Phytopathology 103:55-63.

12. Duressa, D., Rauscher, G., Koike, S. T., Mou, B., Hayes, R. J., Maruthachalam, K., Subbarao, K. V., and Klosterman, S. J. 2012. A realtime PCR assay for detection and quantification of Verticillium dahliae in spinach seed. Phytopathology 102:443-451.

13. França, S. C., Spiessens, K., Pollet, S., Debode, J., De Rooster, L., Callens, D., and Höfte, M. 2013. Population dynamics of Verticillium species in cauliflower fields: Influence of crop rotation, debris removal and ryegrass incorporation. Crop Prot. 54:134-141.

14. Goss, E. M., Larsen, M., Chastagner, G. A., Givens, D. R., and Grünwald, N. J. 2009. Population genetic analysis infers migration pathways of Phytophthora ramorum in US nurseries. PLoS Pathogens 5:e1000583.

15. Gurung, S., Short, D. P. G., Atallah, Z. K., and Subbarao, K. V. 2014. Clonal expansion of Verticillium dahliae in lettuce. Phytopathology 104:641-649.

16. Hall, D., Kimble, A., and Smith, P. 1972. An isolate of Verticillium found pathogenic to wilt-resistant tomatoes. Calif. Agric. 26:3-3.

17. Hayes, R. J., Vallad, G. E., Qin, Q.-M., Grube, R. C., and Subbarao, K. V. 2007. Variation for resistance to Verticillium wilt in lettuce (Lactuca sativa L.). Plant Dis. 91:439-445.

18. Iglesias-Garcia, A. M., Villarroel-Zeballos, M. I., Feng, C., du Toit, L. J., and Correll, J. C. 2013. Pathogenicity, virulence, and vegetative compatibility grouping of Verticillium isolates from spinach seed Plant Dis. 97:1457-1469.

19. Inderbitzin, P., Bostock, R. M., Davis, R. M., Usami, T., Platt, H. W., and Subbarao, K. V. 2011. Phylogenetics and taxonomy of the fungal vascular wilt pathogen Verticillium, with the descriptions of five new species. PLoS ONE 6:e28341.

20. Inderbitzin, P., Davis, R. M., Bostock, R. M., and Subbarao, K. V. 2013. Identification and differentiation of Verticillium species and $V$. longisporum lineages by simplex and multiplex PCR assays. PLoS ONE 8:e65990.

21. Inderbitzin, P., and Subbarao, K. V. 2014. Verticillium systematics and evolution: How confusion impedes Verticillium wilt management and how to resolve it. Phytopathology 104:564-574.

22. Kabir, Z., Bhat, R. G., and Subbarao, K. V. 2004. Comparison of media for recovery of Verticillium dahliae from soil. Plant Dis. 88:49-55.

23. Maruthachalam, K., Atallah, Z. K., Vallad, G. E., Klosterman, S. J., Hayes, R. J., Davis, R. M., and Subbarao, K. V. 2010. Molecular variation among isolates of Verticillium dahliae and polymerase chain reactionbased differentiation of races. Phytopathology 100:1222-1230.

24. Maruthachalam, K., Klosterman, S. J., Anchieta, A., Mou, B., and Subbarao, K. V. 2013. Colonization of spinach by Verticillium dahliae and effects of pathogen localization on the efficacy of seed treatments. Phytopathology 103:268-280.

25. Meyerson, L. A., and Reaser, J. K. 2002. Biosecurity: Moving toward a comprehensive approach: A comprehensive approach to biosecurity is necessary to minimize the risk of harm caused by non-native organisms to agriculture, the economy, the environment, and human health. Bioscience 52:593-600.

26. Milgroom, M. G., and Peever, T. L. 2003. Population biology of plant pathogens: The synthesis of plant disease epidemiology and population genetics. Plant Dis. 87:608-617.

27. Pegg, G. F., and Brady, B. L. 2002. Verticillium Wilts. CABI Publishing, New York.

28. Powell, M., Gundersen, B., Miles, C., Coats, K., and Inglis, D. A. 2013. First report of Verticillium wilt on lettuce (Lactuca sativa) in Washington caused by Verticillium tricorpus. Plant Dis. 97:996-996.

29. Qin, Q.-M., Vallad, G. E., and Subbarao, K. V. 2008. Characterization of Verticillium dahliae and V. tricorpus isolates from lettuce and artichoke. Plant Dis. 92:69-77.

30. Ristaino, J. B. 2002. Tracking historic migrations of the Irish potato famine pathogen, Phytophthora infestans. Microbes Infect. 4:1369-1377.

31. Short, D. P. G., Gurung, S., Maruthachalam, K., Atallah, Z. K., and Subbarao, K. V. 2104. Verticillium dahliae race 2-specific PCR reveals a high frequency of race 2 strains in commercial spinach seed lots and delineates race structure. Phytopathology 104:779-785.

32. Simko, I., Hayes, R. J., Mou, B., and McCreight, J. D. 2014. Lettuce and Spinach. Pages 53-85 in: Yield Gains in Major U.S. Field Crops. S. Smith, B. Diers, J. Specht, and B. Carver, eds. ASA, CSSA, and SSSA, Madison, WI.

33. Singh, R. P., Hodson, D. P., Huerta-Espino, J., Jin, Y., Bhavani, S., Njau, P., Herrera-Foessel, S., Singh, P. K., Singh, S., and Govindan, V. 2011. The emergence of Ug99 races of the stem rust fungus is a threat to world wheat production. Annu. Rev. Phytopathol. 49:465-481.

34. Stukenbrock, E. H., Banke, S., and McDonald, B. A. 2006. Global 
migration patterns in the fungal wheat pathogen Phaeosphaeria nodorum. Mol. Ecol. 15:2895-2904.

35. Subbarao, K. V., Hubbard, J. C., Greathead, A. S., and Spencer, G. A. 1997. Verticillium wilt. Pages 26-27 in: Compendium of Lettuce Diseases. R. M. Davis, K. V. Subbarao, R. N. Raid, and E. A. Kurtz, eds. The American Phytopathological Society, St. Paul, MN.

36. Vallad, G. E., and Subbarao, K. V. 2008. Colonization of resistant and susceptible lettuce cultivars by a green fluorescent protein-tagged isolate of Verticillium dahliae. Phytopathology 98:871-885.
37. Villarroel-Zeballos, M. I., Feng, C., Iglesias, A., du Toit, L. J., and Correll, J. C. 2012. Screening for resistance to Verticillium wilt in spinach and isolation of Verticillium dahliae from seed of spinach accessions. Hortscience 47:1297-1303.

38. Wilhelm, S., Storkan, R., and Sagen, J. 1961. Verticillium wilt of strawberry controlled by fumigation of soil with chloropicrin and chloropicrinmethyl bromide mixtures. Phytopathology 51:744-748.

39. Wu, B. M., and Subbarao, K. V. 2014. A model for multiseasonal spread of Verticillium wilt of lettuce. Phytopathology 104:908-917. 